\title{
ŁUKASZ BARCIŃSKI
}

\section{THE READER'S/TRANSLATOR'S APOPHANY IN THE FACE OF THE LINGUISTIC MEDIUM AS ILLUSTRATED IN THE POLISH TRANSLATION OF GRAVITY'S RAINBOW BY THOMAS PYNCHON AND FINNEGANS WAKE BY JAMES JOYCE*}

\section{Abstract}

The article deals with the complex issue of the interrelation of the elements of the linguistic texture with the elements of sense produced thanks to the decoding of the graphic layer. The departure point for the argument will be the concept of conceptual blending, deriving from cognitive linguistics. This concept describes the blending of two semiotic spaces, here the iconic space and the symbolic space, to create a new emergent space, which escapes unequivocal interpretation, especially if a given text intensifies the role of its graphic form. The analysis of such an emergent space will be understood as a typographic analysis of glyphs, their interdependencies, patterns and, ultimately, their relations with the meaning decoded in a given language. The interpretative act will proceed according to poststructuralist premises, based mainly on the philosophy of Jacques Derrida, who applies the term dissemination to describe the radically ambivalent character of sense production, not limited to semanticism, but taking into consideration all aspects of the textual tissue (graphic, phonetic, syntactic etc.). To describe the specific interpretative state of a reader/translator, who, faced with the totality of an experimental literary work, cannot prioritise various possible ways of interpretation, the study applies

* This article was originally published in Polish in Przektadaniec 2017, vol. 35, pp. 5772. The English version was published with the financial support from the Polish Ministry of Science and Higher Education (DUN grant). 
the term apophany, borrowed from the thought of the German psychologist Klaus Conrad, namely, a stage of development of schizophrenia, which entails a specific experience of abnormal meaningfulness. Examples of a translator's apophany can be found in the analysis of the Polish translation of Gravity's Rainbow by Thomas Pynchon (clusters of letters, punctuation) and Finnegans Wake by James Joyce (the undecidables of the syntagmatic aspect of sentences).

Keywords: apophany, conceptual blending, textual medium, literary translation

\section{Dissemination according to Jacques Derrida}

Without doubt, the interpretation of a literary work is a complicated issue, which has to encompass the entirety of signification processes of a text, taking into account all the possible layers, thanks to which sense can be created, so also the material aspect of the text in its graphic form. The Belgian scholar Paul de Man applies the term "misreading", which presupposes an infinite number of interpretations of a given work, hence the lack of solely one way of reading a text, stressing the fact that a given reading/translation always constitutes an act of a specific interpretation (Culler 1982: 80-81). The French philosopher Jacques Derrida uses the term "dissemination" to describe the radically ambivalent nature of sense production, not limited to a narrowly understood semanticism and including all the aspects of the textual tissue (graphic, phonetic, syntactic, etc.). In the mode of reading - or more precisely: misreading - defined as "ironic", he focuses on textual aporias and elements which are interpretatively undecidable ("undecidables") (Caputo 1987: 147-152), undermining the hermeneutic premise of polysemy, which presupposes the existence of a reducible meaning manifesting itself in different isotopies, consisting in the grouping of basic units of sense (semes) into larger thematically homogenous wholes (Zima 2002: 63). According to Derrida, it is not possible to exhaust the generative potential of textual interpretation since it resonates in other texts and words, consciously or subconsciously, releasing irreducible play between the surplus and lack of meaning in the process of signification, without the possibility of stabilisation or ultimate conclusion (Derrida 1981: 45). Dissemination destroys the hegemonic centre of the text and creates a multitude of filiations which are immanently rooted in it. Derrida calls this state of affairs "the play of the world" (jeu du monde), underlining the contingency of meaning, which questions all that is universal, ontological or transcendental (Derrida 1967: 427). 
"Free play" releases all the repressed vital forces of the signifier, disposing of the metaphysical commitment to privileged semanticism: "from the point of view of meta-physics (which wants to move 'beyond' the substance of the signifier to the signified meaning), Derrida systematically explores all the 'surfaces' of language, all the possible graphic, phonic, rhythmic, and psychoanalytic linkages between words" (Caputo 1987: 148). The aim of dissemination, defined in this way, is to find all the correlations between particular words without reducing meaning only to one layer of the text and undermining the thematic unification of sense, which leads to "a phenomenology of surfaces" (Caputo 1987: 149). To conclude, the written text becomes "an effect of inscription", inevitably contradicting the presence of universal meaning and undergoing infinite re/de-contextualisation (Markowski 2003: 467) in the process of interpretation of "modern hieroglyphs" or "picto-ideo-phonograms" (Hartman 1981: 33). As a consequence, the analysis of a literary work consists in the decoding of symbols found in the text understood as a typographic analysis of glyphs (written signs), their mutual unstable relations and, ultimately, their irreducible connections with the decoded layer of meaning in a given language.

\section{Iconic surplus}

Another term useful for the multifaceted analysis of the textual medium is "iconicity", understood by Peirce as the similarity of a given signifier and a signified (based on the principle of quantity, proximity and sequentiality) not based on any arbitrary assignment. Boase-Beier states that if translation is treated as an autonomous form of writing of an experimental character (2009: 25), the proper strategy for translating any textual nuances (including iconic ones) is "foreignisation" (offered by Venuti), which recreates the stylistic choices by their defamiliarisation and retains the awareness of the difference in the translation process (2009: 105). The irreducibility of the sense of the structure of a literary work is also described by such scholars as Lecercle (1990) and Venuti (1998) as the "remainder", by de Man (1983) as "rhetoric", by Spivak (2004) as "rhetoricity", and by Fonagy as "paralinguistic coding" or "distorter" (Boase-Beier 2009: 104-105). Derrida himself, granting the translation process (as an impossible necessity) the status of an aporia, speaks of the "untranslatable remainder", still calling for the enforcement of the act, which is indispensable for the "afterlife" of the original text 
(Zima 2002: 74-77). The translator, locked in the Derridean impasse or the so-called "double bind" of the necessity to undertake translation and the impossibility of its implementation, has to impose a certain hierarchisation of meaning in the dense network of the textual tissue, choosing from among its numerous layers.

It is worth noticing that the role of the iconic element, referring especially to the graphic or typographic aspect of a given work, does not always gain the respect it deserves from the critics and theoreticians of translation. For example, in the classification offered by Kozak, the translator can focus on three elements: texture, image and sense, to be recreated by homophonic, linguistic and functional translations, respectively (2009: 100-101). Although elements of texture become specified, the method of their translation is the homophonic translation, which focuses on the acoustics and phonetics of the original. Venuti, in a similar vein, as observed Boase-Beier, does not specifically highlight iconic elements, even though it seems that his strategy of foreignisation constitutes a proper avenue to pursue in the translation of works where iconicity comes to the fore (Boase-Beier 2009: 105). Therefore, in any classification of translation strategies, it might be useful to take into consideration also homoglyphic translation, which focuses on the preservation of graphic/typographic features of the original, especially in the era of the predominance of visual culture and the increase in the popularity of hybrid literary projects such as "liberature", a cross-linguistic literary genre, in which the content and space of the book form an inseparable whole (Bazarnik 2002: V-XVI).

\section{Textual spaces}

Another way of perceiving the graphic layer of the text is offered by the American scholar Carl Darryl Malmgren, describing a literary work by means of space ("fictional spaces"). He categorizes these into "textual spaces" and "para-spaces", where the text more intensely interacts with the reader. Spaces referring to the iconicity of the text are divided into "compositional spaces" (the general composition of a work), "paginal spaces" (typography of the page recto and verso), "lexical spaces" (puns, rare and foreign words) and "alphabetic spaces" (the level of particular letters, e.g. anagrams, acrostics). Para-spatial actuation of sense proceeds thanks to the interaction of elements of texture and the elements of sense created by decoding this graphic layer (Malmgren 1985: 45-60). 


\section{GENERIC SPACE}

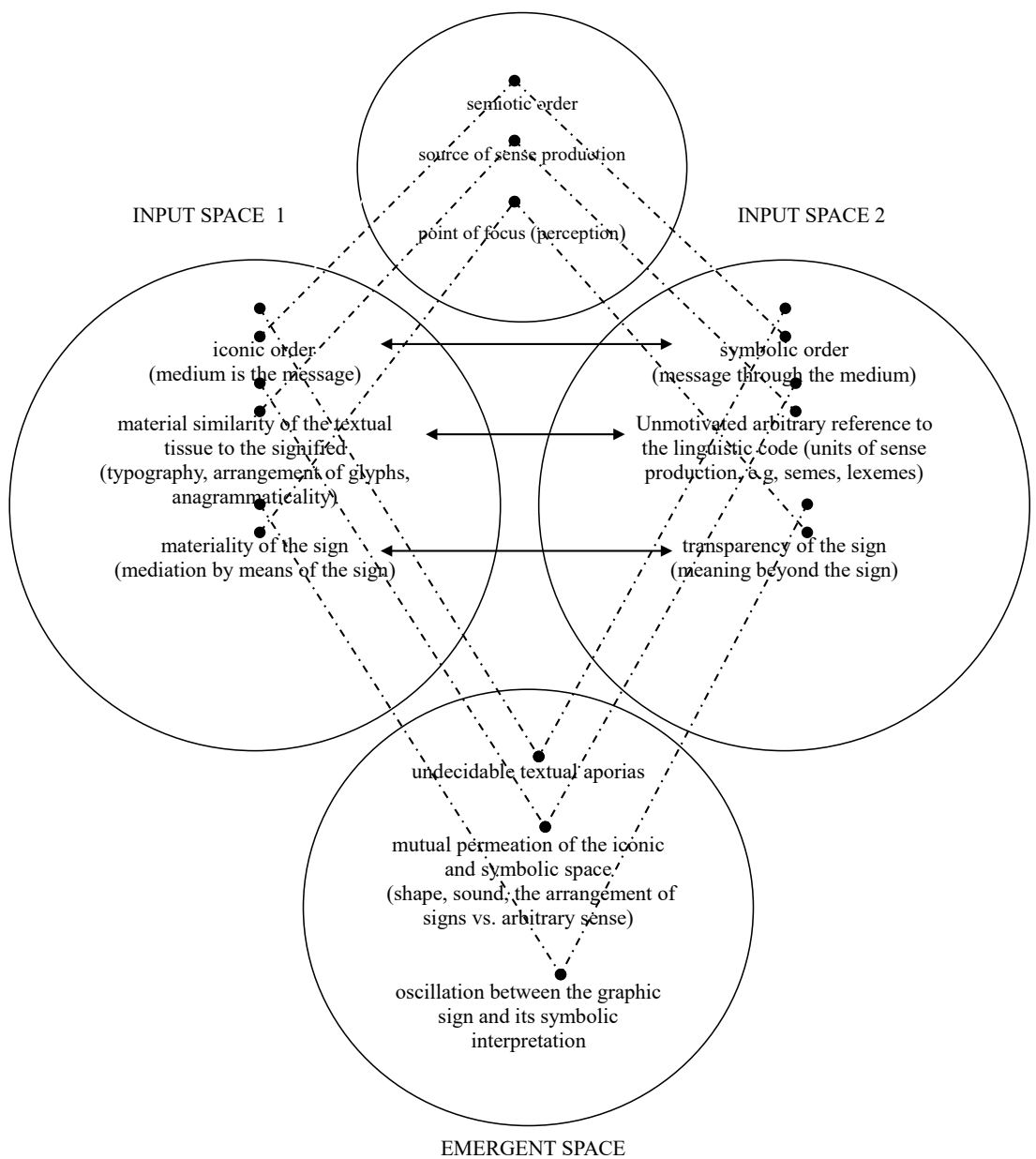

Fig. 1. The undecidable textual elements created in the emergent space as a result of the endless oscillation and permeation of iconic and symbolic aspects of the text

Source: own elaboration. 
From the perspective of cognitive linguistics, a useful term might be "blending", which describes a text as a place of merging of two semiotic spaces, in this case the space of the linguistic medium and the semantic space, in order to create a new structure, often eluding an unequivocal interpretation, especially if - in a given text - the role of the visual form becomes intensified. The theory of conceptual blending, proposed by Gilles Fauconnier and Mark Turner, stipulates that the process of compressing elements from different scenarios is a common phenomenon in everyday language and mental processes: "conceptual blending is a fundamental instrument of the everyday mind, used in our basic construal of all our realities, from the social to the scientific" (Turner 1997: 93). In this theory, two input spaces are merged on the basis of common elements from the generic space to create a new emergent space, i.e. a blending which merges elements from the input domains. It seems that such a definition of conceptual blending or conceptual integration can be a proper tool to investigate the undecidable elements of the textual tissue, consisting in overlapping meanings from different semiotic orders, which is shown in Fig. 1. The result of overlapping the two input spaces (i.e. the blending of iconic and symbolic elements) is the creation of a third space of textual elements interpretatively irreducible in the process of dissemination.

\section{Interpretation and schizophrenia}

An important issue in the interpretation of the blending process, shown in Fig. 1, can be the philosophical perspective connected with the widely defined concept of postmodernism. Even though this term probably has as many meanings as there are scholars who have attempted to define it, there are some convergences in its understanding. One of the indicators of this current of thought, in the second half of the $20^{\text {th }}$ century, is the feeling of a crisis of semiotic meaning, a reference to the end of history and all meta-narratives. The postmodern state of mind, characterised by the lack of rational foundation and omnipresent heterogeneity, is described by many scholars as "multiphrenic" (Gergen 1992), while some associate the late stage of capitalism with schizophrenia (Jameson 1991). Also, Deleuze and Guattari, in their work A Thousand Plateaus: Capitalism and Schizophrenia, present this condition not as a destructive disorder, a pathological state, but as a positive process related to ingenious connectivity (Massumi 1993: 1-4). From this 
perspective, schizophrenia constitutes a certain liberation of perception, and a schizophrenic, as a "body without organs", does not yield to any totalizing influences and, unimpeded, is able to undergo constant transformation. From a psychological perspective, one of the stages of schizophrenia, identified by the German neurologist Klaus Conrad, is "apophany" - or, the unmotivated perception of connections, which is accompanied by "a specific feeling of abnormal meaningfulness". When apophany enters the field of perception no aspect is bereft of meaning, everything suddenly becomes strikingly relevant and it seems that every element of the experienced image has a hidden connection with the observing subject (Conrad 1958: 46). A monotonous and repeated feeling of sense lurking behind the material sign, characteristic of apophany, is related also with the perception of reality as "weirdly beautiful, tantalizingly significant, or perhaps horrifying in some insidious but ineffable way" (Sass 1992: 44), which allows an infinite search for new patterns and analogies without the possibility of any ultimate solution to the interpretative puzzle. Thus, if the term "apophany" becomes appropriated for the purpose of textual interpretation and considered to be a positive state of interpretative undecidability (from the postmodern perspective), it can come to be extremely useful in the comprehension of the process of iconic-symbolic blending. Woods (2011: 201) notices numerous similarities between psychiatric descriptions of schizophrenia and the philosophical description of the postmodern condition made by e.g. Jameson: analogies consist in the dramatisation of the signifying potential of the medium and in highlighting the materiality of the field of perception. The apophenic mode of perception places in the foreground "this present of the world or material signifier [which] comes before the subject with heightened intensity, bearing a mysterious charge of affect (...), which one could just as well imagine in the positive terms of euphoria, a high, an intoxicatory or hallucinogenic intensity" (Jameson 1991: 27-28). In a similar vein, in Deleuze the schizophrenic mode of textual perception is permeated with the materiality of language and the word becomes a physical object (2004: 96-105). If the concept of "apophany" comes to be appropriated for the purpose of textual interpretation (as shown in Fig. 1), the quivering status of the emergent space, related to the impossibility of the stabilisation of meaning, could be analogous to the condition of a subject perceiving the world from the perspective of schizophrenia - understood as a liberating but infinite mode of perception of the materiality of the sign - or to the state of the subject in the interpretative act in the face of an iconic/textual aporia. 


\section{Rainbow and Wake}

The juxtaposition of the two novels, Gravity's Rainbow by Thomas Pynchon and Finnegans Wake by James Joyce, for the purpose of analysis is by no means accidental. Joyce's work, marking a break from modernism, is deemed by many to be the most experimental literary enterprise in history; one which explores the boundaries of linguistic effability. Pynchon's novel, in turn, is a canonical work for the literary current of postmodernism, a characteristic feature of which is the exhaustion of literary devices and techniques to the extreme. Both novels have broken certain canons and irreversibly changed the perception of literary works in general, exploring each and every layer of the textual matter, including the graphic one. However, their common element is, firstly, the fact that both of them depict worlds undergoing neverending obliteration - "worlds under erasure", being constantly "unnarrated", according to McHale's terminology, worlds the ontological status of which is continually destabilised (2012: 108) - and, secondly, that they constitute the perfect linguistic medium for the Apophenic Reader, looking for new semiotic arrangements of sense in every subsequent (mis)reading (Barciński 2016: 241-244).

\section{The textual medium of Gravity's Rainbow in Polish translation}

The Puritan heritage, an important theme in Gravity's Rainbow, manifests itself in "a hieroglyphic sense of concealed meaning" (Pynchon 1972: 17), which makes Pynchon's characters look for material signs in the surrounding reality and, although they often find themselves on the edge of revelation, they never experience it. The Puritan heritage determines the actions of the protagonists, who - like, for instance, Slothrop, an American lieutenantsuccumb to "a Puritan reflex of seeking other orders behind the visible" (Pynchon 1973: 188), which, in turn, leads to a paranoid pursuit of meaning. The textual medium of Gravity's Rainbow smoothly yields to the paranoid (mis)reading defined in such a way, and the interpretative act in Pynchon's works proceeds in "the same way a stargazer perceives a constellation - the configuration of each depends on one's position. From another solar system, a familiar grouping of stars would fall into different patterns" (Cooper 1983: 188). An important aspect is also the theme of Preterites, believers passed 
over by the Creator, for whom there was no room in the Heavenly Kingdom. The fact of omitting the Preterites can be construed as an analogy to the interpretative act performed by the reader/translator, who hegemonically passes over the apparently less relevant elements of the textual tissue in a given misreading.

An example of the translator's apophany, in Gravity's Rainbow, can be the shape of the first letter in the novel, which resembles a rocket ready to be launched and is the reversed V-2 rocket also known as A-4. The first letter shows the initial launch, while the last punctuation mark in the novel, "_-, can be seen as the result of the rocket hitting the target or the flat effect of its destructive force. This typography is not preserved apart from the attempt to recreate the alliteration: screaming $\leftrightarrow$ comes $\leftrightarrow$ across $\leftrightarrow s k y$, which represents the sound of the flying rocket by means of the sibilants: przeszywa↔wskroś.

A screaming comes across the sky. (Pynchon 1973: 3)

Wycie przeszywa niebo na wskroś. (Pynchon 2001: 9)

Now everybody - (Pynchon 1973: 760)

Wszyscy razem — (Pynchon 2001: 598)

As with "any object or event in Pynchon's world, the peripheral as well as the central" (Cooper 1983: 187-188), the double "ss" in "across" starts the signifying chain of associations: it can be the SS emblem, double integral $\iint$ (a mathematical term), "the ancient rune that stands for the yew tree" (Pynchon 1973: 301) or "the shape of lovers curled asleep" (Pynchon 1973: 302). The proliferation of double or more ss alliterations and ss references facilitates infinite sense production related to its possible references to binarity or doubleness in the thematic layer of the text.

In the following example: $S$ 'd against the $S$ of himself - "esowata przy jego esowatości", the iconic shape is not preserved, only the denotation of the letter ("esowatość"). In case of Slothropless ("nie-Slothrop"), the neologism is imprecisely recreated: "nie-Slothrop" suggests a state of being opposite to Slothrop's identity, while Slothropless suggests the lack of his identity as Slothrop.

For a minute he lies coming awake, no hangover, still belonging Slothropless to some teeming cycle of departure and return. Katje lies, quick and warm, S'd against the $\mathbf{S}$ of himself, beginning to stir. (Pynchon 1973: 198) 
Dłuższą chwilę dochodzi do siebie, ani śladu kaca, wciąż nie-Slothrop należący do rozkręconego cyklu odejść i powrotów. Katje leży obok, żywa i ciepła, esowata przy jego esowatości, już zaczyna się poruszać. (Pynchon 2001: 165)

In another example the iconic shape is recreated, but not in the double form:

a moving wood scaffold open on all sides, hoisted by old tarry ropes and castiron pulleys whose spokes are shaped like Ss. (Pynchon 1973: 3-4)

ruchome drewniane rusztowanie, otwarte ze wszystkich stron, wciągane przez stare smołowane liny i żeliwne krążki o szprychach w kształcie litery „, (Pynchon 2001: 10)

The German phonetic version of the English I surrender spelled with double "ss": ei ssörrender, is preserved as pöd-daie ssie, which precisely renders the German phonetic version of the Polish "poddaję się".

One of PWD's classic propaganda leaflets these days urges the Volks-grenadier: SETZT V-2 EIN!, with a footnote, explaining that "V-2" means to raise both arms in "honorable surrender" - more gallows-humor - and telling how to say, phonetically, "ei ssörrender". Is Webley's $\mathbf{V}$ here for victory, or ssörrender? (Pynchon 1973: 230)

W jednej z klasycznych propagandowych ulotek Pionu Walki Psychologicznej zaleca się Volks-grenadierowi: SETZT V-2 EIN!, opatrzywszy tekst przypisem, który wyjaśnia, że "V-2" oznacza podniesienie rąk w "geście honorowego poddania się - kolejna dawka wisielczego humoru - i instruuje, jak odpowiednio wymawiać słowa: "pöd-daie ssie". Czy V Webleya oznacza zwycięstwo czy kapitulację? (Pynchon 2001: 189-190)

In the next case, iconicity is preserved by means of the sibilant and the multiplication of the voiceless " $s$ " instead of the voiced " $z$ ", precisely imitating the idiolect of the German entrepreneur, Walther Rathenau:

„Yess, yess", all staring at him, "but then why keep saying 'mind and body'? Why make that distinction?" (Pynchon 1973: 590)

- Sssgoda, sssgoda - wszyscy patrzą na niego - ale w takim razie dlaczego mówi pan o ciele i umyśle? Po co taka przeciwstawność? (Pynchon 2001: 465)

In the next example the iconicity of "ss" is not recreated: it is replaced by the imitation of the German distortion of particular sounds of the Polish language: naleszy $(\dot{\mathrm{z}} \rightarrow \mathrm{sz})$, włożyć $(\mathrm{l} \rightarrow \mathrm{l}, \dot{\mathrm{z}} \rightarrow \mathrm{z}, \dot{\mathrm{c}} \rightarrow \mathrm{c})$, natychmiazt $(\mathrm{s} \rightarrow \mathrm{z})$. 
"Miss Müller-Hochleben", reading her nametag, "you look beastly without your glasses. Put ssem back on, at vunce!" this comic Nazi routine being inspired by her surname. (Pynchon 1973: 633)

- Droga panno Müller-Hochleben - czytając plakietkę przypiętą na piersi - bez bryli wygląda pani potwornie. Naleszy je wlozyc natychmiazt! - Żartobliwa hitlerowska gadka, zainspirowana nazwiskiem dziewczyny. (Pynchon 2001: $500)$.

\section{The textual medium of Finnegans Wake in Polish translation}

According to Umberto Eco, who appreciates the significance of Finnegans Wake as a wordimage amalgam, the novel constitutes an epiphany of the cosmic structure developed in the space of language, where the linguistic universe merges with the real universe, the texture pours itself out of its own frames and where all the interpretative ambiguities become a metaphor of the impossibility of determination of the reader's/translator's own epistemological or ontological situation (Eco 1998: 184-191). The novel becomes a relativist universe, where every word is a space-time event and its relations to other elements change depending on the position of the observer and the decision which they take in the face of the semantic provocation included in every linguistic item (Eco 1998: 159). Ultimately, the book becomes the quidditas of real experience, an epiphany of the cosmic structure developed in the space of language (Eco 1998: 164). Finnegans Wake has a cyclical structure and should be read as a round object: the number of pages is 628 , which according to the formula of the length of the circle $2 \pi \mathrm{r}$ equals 100 , i.e. the number of letters in thunderwords - onomatopoeic signals stressing the consecutive stages of the work (Bazarnik 2002: vi-x). The typographic iconicity is also manifested in the remotivation of siglas, i.e. graphic abbreviations used by Joyce in the process of writing the novel, which come to life on the pages, initiating an endless chain of associations between the letters, symbols and meanings of words in "the literal interpretation of the signs" (Rabate 1991: 81). Letters remotivated by siglas become transformed into puns, emerge among the words, arrange themselves into different poses, finally to become rightful characters themselves.

An example of the translator's apophany (a situation in which the translator is not able to decide unequivocally about the final translation version in the face of many possible interpretations activated by the amalgamatic 
oscillation of sense) in Finnegans Wake is the famous sentence analysed by Derrida: "And he war", which appears in the fragment referring to the divine origins of language (Markowski 2003: 309):

And shall not Babel be with Lebab? And he war. And he shall open his mouth and answer: I hear, O Ismael, how they laud is only as my loud is one. (Joyce 1975: 258)

Czyż Babel i Lebab nie będą razem? A tak bylon. A ten otworzy usta i odpowie: Słucham, Ismaelu, jak ich bóg jest lauden tak jeden laus mój bóg. (Joyce 2012: 258)

Interpretation of this fragment in terms of superimposition of linguistic codes brings the following results for the word war: 1) the English noun meaning war 2) the German verb war; and 3) the Danish element og han var ("a on byl"). Derrida also points to the conflict reflected in he war related to the history of the Babel Tower. Divine inscription, or God's signature, precludes any attempts to appropriate language in the face of its irremovable polyvocality. As a result, he war embodies the paradoxical status of translation as the dramatisation of the performative divine prohibition: "thou shall not translate" ("I shall wage war upon all those who will undertake translation") and the constative: "he was" where "he" means God himself, called Jahveh (Markowski 2003: 309).

The translation shifts the scene of conflict from the paradigmatic/vertical tension - between war, used by Joyce, and was, expected by the reader- to the syntagmatic/horizontal plane: "a tak byłon", containing the neologism "byłon". The war of linguistic superimposition in the original becomes transformed in the target text into apophenic difficulty in deciphering the proper arrangement of letters in the string of the sentence. The remaining interpretations of the Polish translation include the possible reading of the suffix -on as the English pronoun, suggesting the infiniteness of heteroglottic fight between languages (e.g. "byłon" and on and on), and the recognition of the neologism "byłon" as a nominalisation made by means of the suffix -on, associated with scientific rationalisation (e.g. proton, neutron). In this perspective, the Polish translation replaces the paradigmatic conflict of the original with the neologistic status of the nominalisation: the stability of the process of nominalisation, which usually cools down or tames a given phenomenon (amplified by the "rational" suffix -on) becomes confronted with the indeterminacy in the form of the unconventional first part "byl" 
(the verb "to be" in the past form), which constitutes the driving force of this linguistic mechanism. Moreover, it may be noticed that within the syntagmatic compensation in the translation there are words with military connotations: "atak" ("a" and "tak" read as one word) and "baon" ("byłon" read in a phonetically distorted way may sound as an abbreviated term meaning a battalion).

The case of meanderthale, also analysed by Eco, could again be described as a superimposition of languages: tale (a story in English) + Thal (a valley in German) + Neanderthal + meander create the amalgam of a labyrinthine valley, a primal maze marked by bewilderment and cruelty (Eco 1998: 143). This apophenic moment for the translator in the Polish translation is also rendered by a syntagmatic shift: a meanderthale becomes "A meandron w dal tańczy", which brings the associations of Meander, the Greek god, or the river Meander/Meanderes, which activates the chain of apophenic associations.

What a meanderthale to unfurl and with what an end in view of squattor and anntisquattor and postproneauntisquattor! (Joyce 1975: 19)

A meandron w dal tańczy a jak ma się okończyć a toczy się kład torem, anntisquattorem, postproneauntisquattorem! (Joyce 2012: 19)

Syntagmatic shifts and discontinuities in the target text can be seen as a technique of compensation given the lack of possibility of recreating the simultaneous overlapping of many languages - not heteroglossia, but cross-linguistic heterophemia, words sounding similar in different languages but having different meanings (Szczerbowski 2000: 49). This technique proves to be quite effective, since the syntagmatic change in the linguistic layer has far-reaching consequences in the reception of the text. According to Jameson, the schizophrenic structure of personal temporality (characteristic of the contemporary world) "will determine new types of syntax or syntagmatic relationships" in the individual reception of art (1991: 6). Since a schizophrenic (here a subject performing an act of interpretation of a work of art) suffers from "a breakdown in the signifying chain", their perception becomes reduced to the pure materiality of an ahistorical sign (1991: 27). In other words, the disruption of textual linearity, and the aesthetic of fragmentation characteristic of the postmodern perception of a work of art, are reflected in the translator's technique of compensation. The transfer of perception from paradigmatic relations in the original (war/was) to syntagmatic in the translation ("a tak byłon" vs. 
"atak był on") can be inscribed in the apophenic poetics of Joyce's work, innovatively recreating the irreducibility of the source text.

\section{Conclusion}

For obvious reasons the above analysis of the rendition of iconicity is limited only to selected elements in the translations of the two novels. However, they could be seen as symptomatic for the reception of the whole target texts in the Polish language. The translation of Gravity's Rainbow frequently preserves the symbolic-iconic blending, although more often than not it is not meticulous and does not pay attention to the typographic layer. The translation of Finnegans Wake, in turn, endeavours to render the minutest details of the textual medium and, with reverence, attempts to preserve the surplus of the original, recreating the irreducibility of the original on another linguistic layer.

The present analysis can offer the following conclusions for the practice and theory of translation: the higher the intensification of the wordimage blending, the more possible interpretations a given undecidable element will have and, consequently, it is potentially viable to create a higher number of versions of translation. The amalgams rooted in a given signifying element (signifier) constitute a challenge for the translator, who has to make a difficult decision in the target text - to choose a certain interpretation from many possible ones, which often leads to many losses in translation in comparison to the original. Even though the recreation of all the aspects of the original is an impossible task, every preserved nuance is worth its weight in gold for the recipients of the target texts, yearning for the apophenic jouissance and finding semiotic delight in exploring the vast expanses of textual spaces.

\section{Bibliography}

Barciński Ł. 2016. A Study of Postmodern Literature in Translation as Illustrated Through the Selected Works by Thomas Pynchon, Rzeszów: WUR.

Bazarnik K. 2002. Od Joyce'a do liberatury, Kraków: Universitas.

Boase-Beier J. 2009. Stylistic Approaches to Translation, London: Routledge.

Caputo J.D. 1987. Radical Hermeneutics, Bloomington-Indianapolis: Indiana University Press.

Conrad K. 1958. Die beginnende Schizophrenie, Stuttgart: Thieme Verlag.

Cooper P.L. 1983. Signs and Symptoms, Los Angeles: University of California Press. 
Culler J. 1982. On Deconstruction, Ithaca, New York: Cornell University Press.

Deleuze G. 2004. The Logic of Sense, London: Continuum.

Deleuze G., Guattari F. 2015. Tysiąc Plateau. Kapitalizm i Schizofrenia, Warszawa: Fundacja Bęc Zmiana.

de Man P. 1983. Blindness and Insight: Essays in the Rhetoric of Contemporary Criticism, Minneapolis: University of Minnesota Press.

Derrida J. 1967. L'Ecriture et la difference, Paris: Seuil. 1981. Positions, trans. A. Bass, Chicago: University of Chicago Press.

Eco U. 1998. Poetyki Joyce'a, trans. M. Kośnik, Warszawa: Wydawnictwo KR.

Gergen K.J. 1992. The Saturated Self: Dilemmas of Identity in Contemporary Life, New York: Basic Books.

Hartman G.H. 1981. Saving the Text: Literature/Derrida/Philosophy, Baltimore-London: The John Hopkins University Press.

Jameson F. 1991. Postmodernism, or the Cultural Logic of Late Capitalism, LondonNew York: Verso.

Joyce J. 1975. Finnegans Wake, London: Faber\&Faber.

2012. Finneganów tren, trans. K. Bartnicki, Kraków: Korporacja Ha!art.

Kozak J. 2009. Przeklad jako metafora, Warszawa: Wydawnictwo Naukowe PWN.

Lecercle J.-J. 1990. The Violence of Language: Interpretation as Pragmatics, London: Palgrave.

Markowski M.P. 2003. Efekt inskrypcji. Jacques Derrida i literatura, Kraków: Homini. Malmgren C.D. 1985. Fictional Spaces in the Modernist and Postmodernist American Novel, Lewisburg: Bucknell UP.

Massumi B. 1993. A User's Guide to Capitalism and Schizophrenia: Deviations from Deleuze and Guattari, Cambridge: Massachusetts MIT Press.

McHale B. 2012. "Pynchon's Postmodernism”, in: I.H. Dalsgaard, L. Herman, B. McHale

(eds.), The Cambridge Companion to Thomas Pynchon. Cambridge: Cambridge University Press, pp. 97-111.

Pynchon T. 1972. The Crying of Lot 49, New York: Bantam. 1973. Gravity's Rainbow, New York: Viking Press. 2001. Tęcza grawitacji, trans. R. Sudół, Warszawa: Prószyński i S-ka.

Rabate J.M. 1991. Joyce upon the Void: The Genesis of Doubt, London: MacMillan.

Sass L.A. 1992. Madness and Modernism, New York: Basic Books.

Spivak G.C. 2004. "The Politics of Translation", in: L. Venuti (ed.) The Translation

Studies Reader, London-New York: Routledge, 397-416.

Szczerbowski T. 2000. Anna Livia Plurabelle po polsku, Kraków: WNAP.

Turner M. 1997. The Literary Mind, Oxford: Oxford University Press.

Woods A, 2011. The Sublime Object of Psychiatry: Schizophrenia in Clinical and Cultural Theory, Oxford: Oxford University Press.

Venuti L. 1998. The Scandals of Translation, London-New York: Routledge. (ed.) 2004. The Translation Studies Reader, London-New York: Routledge.

Zima P.V. 2002. Deconstruction and Critical Theory, London-New York: Continuum. 